\title{
ANALISIS KONSUMSI DAGING BABI OLEH MASYARAKAT PESISIR DANAU TONDANO
}

\author{
Brigita K. M. Kumaat, F. H. Elly*, E. Wantasen, L.S Kalangi \\ Fakultas Peternakan Universitas Sam Ratulangi Manado, 95115
}

\begin{abstract}
ABSTRAK
Produk peternakan dibutuhkan masyarakat dalam rangka meningkatkan kualitas sumberdaya manusia.Daging babi sebagai salah satu produk peternakan yang dikonsumsi oleh masyarakat pesisir Danau Tondano.Permasalahannya konsumsi produk daging babi ditentukan oleh berbagai faktor.Berdasarkan permasalahan tersebut maka telah dilakukan penelitian dengan tujuan untuk menganalisis faktorfaktor yang mempengaruhi konsumsi daging babi oleh masyarakat pesisir Danau Tondano.Penelitian ini dilakukan dengan menggunakan metode survey.Pengambilan sampel ditentukan dengan menggunakan metode Stratified Random Sampling. Data yang digunakan adalah data primer dan data sekunder. Jenis data adalah data cross section. Analisis data yang digunakan adalah analisis persamaan tunggal dengan menggunakan software program SAS 9.4.Hasil penelitian menunjukkan bahwa daging babi yang dikonsumsi sebanyak 15,02 gr/kapita/hari. Berdasarkan hasil penelitian dapat disimpulkan bahwa konsumsi daging babi secara bersamasama dipengaruhi oleh pendapatan rumahtangga, umur ibu, dan jumlah anggota keluarga.Pendapatan rumahtangga dan jumlah anggota keluarga berpengaruh sangat nyata terhadap konsumsi daging babi. Karena itu masyarakat pesisir, perlu sosialisasi pentingnya protein hewani berasal dari produk peternakan khususnya daging babi.
\end{abstract}

Kata Kunci: Konsumsi, Daging Babi, Masyarakat Pesisir

*Korespondensi (corresponding author):

E-mail: femihelly@unsrat.ac.id

\section{ABSTRACT}

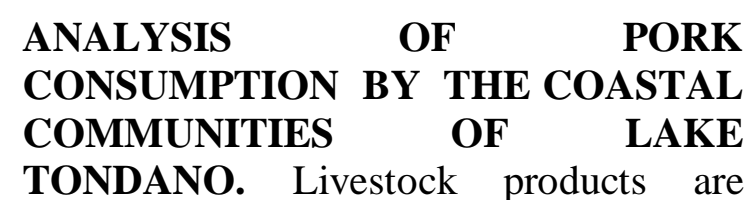
needed by the community in order to improve the quality of human resources.Pork meat is one of the livestock products consumed by community on the coast of Lake Tondano.The problem is consumption of pork is determined by various factors. Based on these problems, a study was conducted with the aim of analyzing the factors that influence the consumption of pork by the coastal communities of Lake Tondano.This research was conducted using a survey method. Sampling was determined using the Stratified Random Sampling method.The data used are primary and secondary data. Data type is cross section data. Analysis of the data used is the analysis of a single equation using the SAS 9.4 software program. The study showed that pork consumed as much as $15.02 \mathrm{gr} /$ capita / day. Factors influenced pork consumption by households were income, age of housewife, and number of family members. The consumption of pork is significantly influenced by household income and the number of family members.

Keywords: consumption, pork meat, coastal community

\section{PENDAHULUAN}

Meningkatnya jumlah penduduk dan adanya perbaikan kesejahteraan masyarakat beberapa daerah di Indonesia berdampak terhadap peningkatan laju 
kebutuhan pangan.Fenomena tersebut terus berlanjut sampai saat ini.Pangan terdiri dari pangan nabati dan hewani.Pangan hewani bersumber dari produk ikan dan produk peternakan.Sejalan dengan dinamika kebutuhan konsumsi pangan produk peternakan menyebabkan berubahnya komposisi menu makanan rumahtangga kearah yang lebih baik.Kenyataan ini menunjukkan bahwa arah permintaan komoditas pangan produk peternakan di masa mendatang akan semakin beragam.

Produk peternakan sangat dibutuhkan dalam menopang tubuh manusia sehingga kualitas sumberdaya manusia meningkat menjadi lebih baik.Hal ini karena produk peternakan memiliki kandungan gizi yang dapat menunjang kebutuhan nutrisi bagi masyarakat.Produk peternakan dalam hal ini memiliki skor tertinggi sebagai sumber protein hewani sehingga produk ini memiliki peranan strategis dalam pencapaian kebutuhan gizi konsumsi pangan yang baik (Winda, 2016).Menurut Muzayyarah et al. (2017), konsumsi pangan sumber protein hewani meningkat seiring meningkatnya tingkat pendapatan.

Konsumsi produk peternakan berkaitan erat dengan kemampuan atau daya beli masyarakat.Produk peternakan dalam hal ini bersifat elastis terhadap pendapatan masyarakat.Menurut Giang
(2013) bahwa terdapat hubungan yang erat dan positif antara tingkat pendapatan dengan pola konsumsi.Produk peternakan termasuk daging babi umumnya memiliki harga yang relatif tinggi.Tingkat sosial ekonomi masyarakat yang semakin tinggi menyebabkan porsi pengeluaran konsumsi bergeser dari pengeluaran untuk pokok pangan ke pengeluaran sekunder.Sebaliknya rendahnya porsi pengeluaran konsumsi pangan pokok dan tingginya porsi pengeluaran sekunder berdampak terhadap meningkatnya kesejahteraan masyarakat (Yuliandri, 2015).Masyarakat dalam mengkonsumsi produk peternakan dalam hal ini harus mempertimbangkantingkat pendapatan yang diperoleh (Badoa, 2016).

Daging babi sebagai salah satu produk peternakan yang dikonsumsi oleh masyarakat pesisir Danau Tondano.Permasalahannya konsumsi produk daging babi ditentukan oleh berbagai faktor.Berdasarkan permasalahan tersebut maka telah dilakukan penelitian dengan tujuan untuk menganalisis faktorfaktor yang mempengaruhi konsumsi daging babi oleh masyarakat pesisir Danau Tondano.

\section{METODE PENELITIAN}

Lokasi penelitian di daerah pesisir Danau Tondano, Kabupaten Minahasa Sulawesi Utara. Metode penelitian ini 
menggunakan metode survey. Pengumpulan data menggunakan teknik wawancara pada responden masyarakat petani dengan menggunakan kuesioner yang telah disiapkan.Jenis data yang dikumpulkan adalah data Cross Section.Sumber data penelitian adalah data primer dan data sekunder.Data primer diperoleh dari masyarakat petani melalui metode survey.Sedangkan data sekunder diperoleh dari instansi yang terkait dengan penelitian ini.Tahapan pengumpulan data primer terdiri dari tahap identifikasi wilayah sampai pada pengumpulan data konsumsi rumahtangga masyarakat petani.

Dalam penelitian ini, populasi yang digunakan adalah masyarakat pesisir danau Tondano. Penentuan sampel dilakukan secara Stratified Random Samplingyaitu pengambilan sampel acak terstratifikasi yaitu metode pemilihan sampel dengan cara membagi populasi ke dalam kelompok-kelompok yang homogen yang disebut strata, dan kemudian sampel diambil secara acak dari tiap strata tersebut(Arikunto, 2006). Tahap pertama dalam penentuan sampel yaitu menentukan populasi.Populasi pada penelitian ini yaitu masyarakatdi pesisir Danau Tondano.Selanjutnya diambil 3 kecamatan dengan jumlah penduduk terbanyak di pesisir Danau Tondano yaitu Kecamatan Remboken, Kakas dan Tondano Selatan.Selanjutnya dipilih 2 desa dari masing-masing kecamatan yang berada tepat di pesisir Danau Tondano untuk diambil sampel.Sampel pada penelitian ini yaitu petani/peternak yang berada di pesisir Danau Tondano.Jumlah sampel ditentukkan dari jenis pekerjaan.Jumlah rumahtangga petani/peternak yang menjadi sampel berjumlah 57 orang.Data hasil penelitian dianalisis menggunakan pendekatan ekonometrika dengan model regresi bergandadan softwareyang digunakan adalah SAS 9.4. Bentuk persamaan regresi tersebut dinyatakan dalam persamaan 1 berikut:

$$
C D b=a+P R T+U I B U+J A K
$$

Keterangan:

$$
\begin{aligned}
\mathrm{CDb} & =\text { Konsumsi Daging Babi(kg/thn) } \\
\text { PRT } & =\text { Pendapatan Rumahtangga } \\
& (\text { Rp/thn }) \\
\text { UIBU } & =\text { Umur Ibu (tahun) } \\
\text { JAK } & =\text { Jumlah Anggota Keluarga (orang) }
\end{aligned}
$$

\section{HASIL DAN PEMBAHASAN}

Hasil penelitian menunjukkan bahwa distribusi umur responden berkisar pada 46-60 tahun (44 persen), kemudian diikuti kelompok umur 31-40 tahun (28 persen). Umur responden tersebut dikategorikan sebagai umur produktif.Kategori umur produktif menunjukkan bahwa responden lebih mudah dalam mengadopsi ilmu pengetahuan termasuk informasi berkaitan dengan pentingnya konsumsi produk peternakan.Hal ini ditunjang oleh hasil 
penenlitian Ambat (2011) yang menunjukkan bahwa indikasi umur produktif adalah mudahnya mereka dalam merespon adanya informasitermasuk informasi tentang pentingnya konsumsi protein hewani asal ternak.

Hasil penelitian menunjukkan bahwa tingkat pendidikan dari responden bervariasi mulai dari tingkat Sekolah Dasar (SD) sampai dengan Perguruan Tinggi (S1).Tingkat pendidikan responden terbanyak pada tamat SMP (46 persen), tamat Perguruan Tinggi sebesar (26 persen), tamat SMA (21 persen) serta tamat SD (7 persen).Tingkat pendidikan responden dikategorikan masih rendah, sehingga berpengaruh terhadap keputusan konsumsi.Pengetahuan tentang gizi yang baik berdampak terhadap kemampuan seseorang dalam menentukan menu yang baik untuk dikonsumsi (Ellyet al., 2018).

$$
\text { Pendapatan rumahtangga }
$$

berdampak terhadap tinggi rendahnya konsumsi produk peternakan termasuk daging babi.Pendapatan dalam penelitian ini adalah jumlah penghasilan riil dari seluruh anggota rumah tangga yang disumbangkan untuk memenuhi kebutuhan bersama maupun perseorangan dalam rumahtangga.Rumahtangga didefinisikan sebagai seseorang atau sekelompok orang yang mendiami sebagian atau seluruh bangunan fisik dan biasanya makan bersama dari satu dapur (BPS,2014). Hasil penelitian menunjukkan bahwa rumahtangga yang berpendapatan $<\mathrm{Rp}$ 1.000.000,- per bulan sebanyak 21 responden (37 persen). Rumahtangga yang memiliki pendapatan keluarga berkisar antara Rp 1.000.000,- sampai Rp 3.000.000,- per bulan sebanyak 21 responden (37 persen) dan pendapatan di atas Rp 3.000.000,- per bulan yaitu sebesar 15 responden (26 persen).

Masyarakat yang ada di Kabupaten Minahasa pada khususnya dan Sulawesi Utara pada umumnya mengkonsumsi daging yang dibeli di Pasar Tradisional, Pasar Swalayan, dan tidak sedikit yang mengkonsumsi hasil ternak sendiri. Hasil penelitian menunjukkan bahwa masyarakat yang ada di Kecamatan Tondano Selatan, Remboken, dan Kakas cenderung memilih pasar tradisional dibandingkan pasar swalayan untuk membeli daging yang akan dikonsumsi. Alasan konsumen atau responden membeli daging di pasar tradisional karena mudah terjangkau.Berdasarkan data yang diperoleh pada saat penelitian bahwa masyarakat sudah memberikan respon yang baik dalam mengkonsumsi daging.Tingkat konsumsi masyarakat yang cukup dikarenakan adanya kesadaran masyarakat mengenai pentingnya nilai gizi yang terkandung dalam daging sebagai sumber protein hewani. Hasil penelitian menunjukkan bahwa daging babi yang 
dikonsumsi rumahtangga sebanyak $25,7 \mathrm{~kg}$ per bulan. Hasil penelitian Osak et al, (2014) menunjukkan bahwa 70 persen masyarakat mengkonsumsi daging babi. Hasil analisis regresi pengaruh beberapa faktor terhadap konsumsi daging babi, dengan menggunakan software program SAS 9.4, dinyatakan dalam Tabel 1. Hasil analisis regresi seperti pada Tabel 1.Hasil analisis regresi pada Tabel 1 dapat ditunjukkan dalam bentuk persamaan regresi.Bentuk persamaan regresi tersebut dinyatakan dalam persamaan (2).

$\mathrm{CDb}=1.432+0.530 \mathrm{PRT}+0.009$

$\mathrm{UIBU}+0.698 \mathrm{JAK}$

Keterangan :

$\mathrm{CDb}=$ Konsumsi Daging Babi (kg/tahun)

PRT $=$ Pendapatan Rumahtangga (Rp/tahun)

UIBU = Umur Ibu (tahun)

JAK = Jumlah Anggota Keluarga (orang)

Hasil analisis uji F (Tabel 1) menunjukkan bahwa variabel pendapatanrumahtangga, umur ibu, dan jumlah anggota keluarga secara bersamasama berpengaruh nyata terhadap konsumsi daging babi berpengaruh nyata terhadap konsumsi daging babi $(\mathrm{P}<0.05)$. Selanjutnya, nilai R-Square $\left(\mathrm{R}^{2}\right)$ yang diperoleh sebesar 0.85237 , artinya variasi naik turunnya konsumsi daging babi, 85,24 persen disebabkan karena variasi naik turunnya pendapatan rumahtangga, umur ibu dan jumlah anggota keluarga. Sisanya 14, 76 persen ditentukkan oleh variabel lain yang tidak dimasukkan dalam model.

Nilai intersep sesuai hasil analisis (Tabel 1) menunjukkan bahwa nilai intersep sebesar 1.432, artinya tanpa adanya variabel pendapatan, umur ibu dan jumlah anggota keluarga maka konsumsi daging babi oleh masyarakat pesisir sebesar 1.432 kg.indikasinya bahwa masyarakat pesisir danau Tondano tetap mengkonsumsi daging babi walaupun tidak ada pendapatan, umur ibu dan jumlah anggota keluarga. Bahsan pangan termasuk produk peternakan daging babi yang dipilih masyarakat secara individu dipengaruhi oleh beberapa atribut personal diantaranya lingkungan sosial yang berkaitan dengan norma, budaya, ekonomi dan ketersediaan produk peternakan tersebut (Hidayah, 2011). Ariani et al. (2018), menyatakan bahwa kualitas protein hewani lebih baik dibandingkan protein nabati karena asam amino yang terkandung didalamnya lebih lengkap dan daya serap dalam tubuh juga lebih tinggi. 
Tabel 1. Hasil Analisis Regresi Konsumsi Daging Babi

\begin{tabular}{lccl}
\hline Variabel & Koefisien & t hit & $\operatorname{Pr}>|\mathrm{t}|$ \\
\hline Intercept & 1.432 & -5.01 & $<.0001$ \\
PRT & 0.529 & 6.76 & $0.0002^{* *}$ \\
UIBU & 0.009 & 1.65 & 0.1053 \\
JAK & 0.698 & 3.08 & $0.0032^{* *}$ \\
\hline F value & 105.85 & & \\
Pr $>$ F & $<.0001 * *$ & \\
$\mathrm{R}^{2}$ & 0.85237 & & \\
$* *$ signifikan pada $\alpha, 0,01(\mathrm{P}<0,01)$ & &
\end{tabular}

Nilai koefisien regresi sesuai hasil analisis (Tabel 1) dan Persamaan 2) menunjukkan variabel pendapatan rumahtangga (PRT) sebesar 0.529.Artinya bila pendapatan rumahtangga naik satu rupiah maka konsumsi daging babi naik $\begin{array}{lll}\text { sebesar } & 0.530 \quad \mathrm{~kg} \text {,ceteris }\end{array}$ paribus.Berdasarkan hasil uji t (Tabel 1) dapat dinyatakan bahwa pendapatan rumahtangga berpengaruh nyata terhadap konsumsi daging babi $(\mathrm{p}<0.05)$.Hal ini sesuai dengan hasil penelitian (Osak et al.,2014; Weol et al.,2014; Keintjem et al., 2016)bahwa pendapatan berpengaruh nyata terhadap konsumsi daging babi.

Nilai koefisien regresi sesuai hasil analisis (Tabel 1 dan Persamaan 2) menunjukkan variabel umur ibu rumahtangga (UIBU) sebesar 0.009. Artinya bila umur ibu rumahtangga bertambah satu tahun maka konsumsi daging babi naik sebesar $0.009 \mathrm{~kg}$, ceteris paribus. Berdasarkan hasil uji t (Tabel 1) dapat dinyatakan bahwa umur ibu rumahtangga berpengaruh tidak nyata terhadap konsumsi daging babi $(\mathrm{p}<0.05)$.Indikasinya dalam penelitian ini bahwa umur ibu pengaruh kecil dalam keputusan untuk mengkonsumsi daging babi.

Nilai koefisien regresi sesuai hasil analisis (Tabel 1 dan Persamaan 2) menunjukkan variabel jumlah anggota keluarga (JAK) sebesar 0.698. Artinya bila jumlah anggota keluarga bertambah satu orang maka konsumsi daging babi naik sebesar $0.698 \mathrm{~kg}$, ceteris paribus. Berdasarkan hasil uji t (Tabel 1) dapat dinyatakan bahwa jumlah anggota keluarga berpengaruh nyata terhadap konsumsi daging babi $(\mathrm{p}<0.05)$.Fenomena ini menunjukkan bahwa bertambahnya anggota keluarga berdampak terhadap keputusan konsumsi daging babi.Pola 
demografi berdampak terhadap penyediaan dan konsumsi pangan produk peternakan (Satterthwaite et al., 2010; Elly et al., 2015)

\section{KESIMPULAN}

Berdasarkan hasil penelitian dapat disimpulkan bahwa konsumsi daging babi secara bersama-sama dipengaruhi oleh pendapatan rumahtangga, umur ibu, dan jumlah anggota keluarga.Pendapatan rumahtangga dan jumlah anggota keluarga berpengaruh sangat nyata terhadap konsumsi daging babi.

Saran yang disampaikan kepada masyarakat pesisir, perlu sosialisasi pentingnya protein hewani berasal dari produk peternakan khususnya daging babi.

\section{DAFTAR PUSTAKA}

Ambat, A. G. 2011. Analisis Konsumsi Daging di Kecamatan Tikala Kota Manado. Skripsi. Jurusan Sosial Ekonomi Fakultas Peternakan Universitas Sam Ratulangi. Manado.

Ariani, M., A. Suryana., S.H. Suhartini dan H.P. Saliem.2018. Keragaan konsumsi pangan hewani berdasarkan wilayah dan pendapatan di tingkat rumah tangga. Jurnal Analisis Kebijakan Pertanian 16(2): 147-163.

Arikunto, S. 2006. Metode Penelitian Kualitatif. Bumi Aksara, Jakarta

Badan Pusat Statistik. 2014. Pengeluaran Untuk Konsumsi Penduduk Indonesia Per Provinsi. Survei Sosial Ekonomi Indonesia. Buku 3, Jakarta.
Badoa, I. V. A.H.S. Salendu, F.H. Elly dan P.O.V. Waleleng. 2016. Pengaruh pendapatan terhadap konsumsi daging dan telur di kecamatan Siau Barat kabupaten Kepulauan Siau Tagulandang Biaro. Jurnal Zootec 36(1):61-68.

Elly, F.H., M. Manese., N.M. Santa and I.D.R. Lumenta. 2015. Analysis of livestock product consumption coastal household in North Minahasa Regency. Procedia Food Science 3(1) : 364-370.

Elly, F.H., M.A.V. Manese, J.C. Loing., R. Pamolango, A. Makalew and E. Wantasen. 2018. Food consumption of livestock product by household coast in South Bolaang Mongondow Regency, North Sulawesi, Indonesia. Advances in Nutrition and Food Science 3(1) :1-5.

Giang, R. R. 2013. Pengaruh pendapatan terhadap konsumsi buruh bangunan di kecamatan Pineleng. Jurnal EMBA1(3) : 248-256.

Hidayah, N. 2011.Kesiapan psikologis masyarakat pedesaan dan perkotaan menghadapi diversifikasi pangan pokok. Jurnal Humanitas 8(1): 84-104.

Keintjem, R., F.S.G. Oley., G.D. Lenzun dan J. Pandey. 2016. Pengaruh pendapatan terhadap konsumsi daging babi di kecamatan Wanea kelurahan Ranotana Weru. Jurnal Zootec36(1): 139-146.

Muzayyanah, M.A.U., S. Nurtini dan R. Widiati. 2017. Analisis keputusan rumahtangga dalam mengkonsumsi pangan sumber protein hewani asal ternak dan non ternak: studi kasus di Provinsi Yogyakarta. Buletin Peternakan 41(2) :203-211. 
Osak, R. A. F., V.V.J.Panelewen, J. Pandey dan I.D.R. Lumenta, 2014. Pengaruh pendapatan rumahtangga terhadap konsumsi daging (sapi, babi, ayam) di desa Sea I kecamatan Pineleng. Jurnal Zootec 34(2) : 10-17.

Satterthwaite, D., G.M. Granahan and C. Tacoli. 2010. Urbanization and its implications for food and farming. Philosophical Transactions B 365(1554) : 2809-2820.
Weol. F. E., B. Rorimpandey, G. D. Lenzun dan E. K. M. Endoh. 2014. Analisis pengaruh pendapatan rumahtangga terhadap konsumsi daging di kecamatan Suluun Tareran Kabupaten Minahasa Selatan. Jurnal Zootec 34(1) : 3747.

Yuliandri, L. A. 2015. Pola dan perilaku konsumsi pangan asal ternak pada rumah tangga peternak sapi perah di Jawa Tengah. Agrivet Jurnal 3(2):1-11. 